\title{
Measuring the Interest of Smartphone Usage by Using Technology Acceptance Model Approach*
}

\author{
Yohan WISMANTORO ${ }^{1}$, Heribertus HIMAWAN², Karis WIDIYATMOKO ${ }^{3}$
}

Received: July 03, 2020 Revised: July 19, 2020 Accepted: August 10, 2020

\begin{abstract}
The development of mobile Internet services allows more consumers to adopt smartphones as their primary communication device. This study focused on the application of the Technology Acceptance Model (TAM) to determine the willingness of batik and textile craftsmen to use smartphones. The population of this study was batik and textile craftsmen in the Bayat, Klaten, Central Java, Indonesia. A total sample of 243 people had answered 30 questions on the questionnaire with a 5-point Likert scale. The results of data analysis using GSCA software showed that, from eight hypotheses proposed, two hypotheses had not been supported. Technical support was not significant for the ease-ofuse. It is because the damage experienced can be easily resolved by a repair shop. The findings reinforce the importance of training during the implementation of new technology. This training can make the users understand how to use new technology. The findings of this study strengthen the theory of TAM. Management support further influences the usefulness. This finding supports the theory of Igbaria technology acceptance. However, social influence did not significant influence the usefulness. This was because this study was conducted when the smartphone was no longer said to be a new technology.
\end{abstract}

Keywords: Ease of use, Usefulness, Technology Acceptance Model

JEL Classification Code: C38, D70, M21

\section{Introduction}

The growth of cellular business shows very rapid development (Park, Yap, \& Makkar, 2019; Choi, 2018; eMarketer, 2017; Sagib \& Zapan, 2014). Along with the development of mobile Internet services, more consumers consider smartphones as their primary communication device.

\footnotetext{
*Acknowledgements:

This research is funded by the Ministry of Research, Technology, and Higher Education in 2019 the Strategic National Competitive Research Grant Program, number 085/A.38.04/UDN-09/IV/2019.

${ }^{1}$ First Author and Corresponding Author. Lecturer, Business and Economics Faculty, Universitas Dian Nuswantoro, Semarang, Indonesia [Postal address: JI. Nakula I No. 5-11 Semarang, 50131, Indonesia] E-mail: yohan.wismantoro@dsn.dinus.ac.id

${ }^{2}$ Lecturer, Faculty of Computer Science, Universitas Dian Nuswantoro, Semarang, Indonesia.

${ }^{3}$ Lecturer, Faculty of Computer Science, Universitas Dian Nuswantoro, Semarang, Indonesia.

(c) Copyright: The Author(s)

This is an Open Access article distributed under the terms of the Creative Commons Attribution Non-Commercial License (https://creativecommons.org/licenses/by-nc/4.0/) which permits unrestricted non-commercial use, distribution, and reproduction in any medium, provided the original work is properly cited.
}

This certainly caused the smartphone sales significantly increased worldwide (Pipitwanichakarn \& Wongtada, 2019). The operating system used on some phones can vary, but most use an operating system based on Android, iOS, and Windows Mobile. However, most of the operating systems currently used by various handsets from various manufacturers is the Android-based operating system, accounting for $50.9 \%$ of the world market (Marinkovic \& Kalinic, 2017).

Based on the data from the Indonesian Ministry of Communication and Information, cellular phone customers in Indonesia reached 435.19 million customers in 2017. Compared to the number of cellular phone users in 2011 , which was 249.8 million, there was an increase of $49.6 \%$. With the growing popularity of mobile phones, it is expected that more business transactions will also use smartphones. According to data from www.statista.com, the number of mobile applications (apps) registered on Google Play as of March 2019 was 2.6 million. There are various applications, such as games, books, chat, TV, magazines, banks, and music. Although the use of this technology is not free of risk (such as viruses, data theft, other kinds of theft, damage to 
the device, the use of mobile phones as a proxy to establish virtual connections from the attacker to the internal network, Malformed Short Message Service), however, the role of mobile/smartphone users will be increasingly important in creating business excellence (Biljon \& Kotze, 2009; Grob, 2015; Choi, 2018).

Responding to the existing phenomenon explained above, Bank Indonesia has conducted a branchless banking trial by utilizing the optimal use of mobile phones as well as collaboration with local units/agent. The aim of this program is the unbanked and underbanked communities. Branchless banking was further expanded to be a digital financial service (DFS), which is a payment system and financial services carried out in collaboration with third parties where mobile and web-based technology devices in the framework of inclusive finance are used (PBI 16/ 8 /PBI/2014). DFS is the spearhead of financial inclusion. It is one of the efforts to increase technology-based economic activities. DFS has the potential to be developed based on a survey conducted by APJII. The results of the survey revealed that more than half of Indonesia's population (132.7 million) is connected to the internet.

Apart from the potential and the role of technology use from $\mathrm{m}$-shopping, the field of $\mathrm{m}$-shopping can still be further investigated (Grob, 2015). The available literature is mostly dominated by anecdotal discussions about the development of cellular technology, its functions and benefits, cellular marketing campaigns, and service provider business activities. The more systematic academic study usually focuses on consumer attitudes and m-shopping acceptance based on the Technology Acceptance Model (Davis, 1989; Kapoor et al., 2014). However, functional attributes such as the perceived benefits and ease-of-use (derived from TAM) do not exclusively encourage m-shopping. The motivation of consumer consumption can be embedded socially and culturally in the lives of consumers (Park, Yap, \& Makkar, 2019).

MSMEs are economic agents that make a large contribution to the economy. However, their ability to access formal financial institutions is often constrained by various procedures and requirements that cannot be met, which hamper business development. The implementation of DFS in MSMEs will increase opportunities to obtain financial services, reach broader markets, and be able to accommodate small-value, high-frequency transactions. For micro-small entrepreneurs vulnerable to cash transfers, DFS is a non-cash payment device that can avoid leakage of funds. One of the most reliable and developing MSMEs in Indonesia is Batik and textile products, one of which is located in Klaten Regency.

Bayat is a village located in Klaten Regency, Central Java Province. It is one of the centers of traditional batik and textiles which have been marketed abroad to the United Kingdom, Italy, America, and Asia. Since the scope of its business is global, the use of global technology in transactions has to be further developed. If the marketing strategy has been carried out using the web and exhibitions, then the transaction and payment technology needs to be developed. The problem of this study was the factors that affect craftsmen's willingness to use a smartphone in their business transactions.

\section{Literature Review and Hypotheses}

This study focused on the application of TAM to determine the willingness level of craftsmen to use smartphones and the variables in TAM that affect the willingness. To be able to use technology properly as well as to improve the quality of its work, technical support is needed in the form of guidance, training, and consultation in using technology (Ardiansah, Chariri, Rahardja, \& Udin, 2020; Lee, Becker, \& Potluri, 2016; Marakarkandy, Yajnik, \& Dasgupta, 2017; Igbaria, 1994; Igbaria et al., 1997). The high level of technical support is expected to increase confidence about the benefit of applying technology among individuals (Igbaria et al., 1997). Also, technical support has a significant positive effect on perceived ease of use (Barhoumi, 2016; Kwak et al., 2012).

\section{H1: Technical support affects the ease-of-use.}

Training is defined as a broader and deeper explanation related to systems intended for users and presented by internal and external sources. Training is an important factor affecting the acceptance of technology in organizations (Cheney et al., 1986). Appropriate training will increase the likelihood, and IT implementation will be acceptable because training provides a better understanding and experience of technology (Raymond, 1988; Venkatesh \& Morris, 2000). Training has a significant positive impact on perceived ease of use (Igbaria et al., 1997; Son et al., 2012; Kwak et al., 2012).

\section{H2: Training affects the perceived ease-of-use.}

In context of IT use, job suitability is defined as an individual's perception of the extent to which new technology is appropriate for his work (Venkatesh \& Morris, 2000). Individual attitudes towards new technology are influenced by the characteristics of their work (Son et al., 2012). Empirical studies found that Job Relevance has a significant positive effect on perceived usefulness (Venkatesh \& Morris, 2000; Pérez et al., 2004). 


\section{H3: Job relevance affects usefulness.}

Management support is defined as the individual's perception of the extent to which top management understands the importance of IT and the extent to which top management is involved in IT implementation (Ragu-Nathan et al., 2004). Top management support is an important factor in acceptance technology (Igbaria, 1994; Igbaria, 1997). A strong commitment from leadership is very important to ensure the acceptance of technology by creating an environment that supports IT in organizations. The previous study had found that management support significantly influences perceived usefulness (PU) (Igbaria et al., 1997; Lewis, Agarwal, \& Sambamurthy, 2003; Son et al., 2012).

\section{H4: Management support affects usefulness.}

According to the diffusion of innovation theory developed by Rogers (1995), an individual's decision to adopt a new type of technology in influenced by social forces to fulfill one's desires or because of others' opinions. Social influence is the key to the emergence of IT acceptance theories, such as reason action theory (Fishbein \& Ajzen, 1975), planned behavior theory (Ajzen, 1985), technology acceptance model (Davis, 1989), and the unified theory of acceptance and use of technology (Venkatesh et al., 2003). Social influence has a positive impact on perceived usefulness (Venkatesh \& Morris, 2000; Lee, Lee, \& Lee, 2006; Son et al., 2012).

\section{H5: Social influence affects usefulness.}

Someone's positive or negative attitude on cellphone use is based on their valuation of the usability and ease of use (Nguyen \& Luu, 2020; Taylor \& Todd, 1995). Previous studies had shown that there is a significant and positive influence between perceived ease of use and perceived usefulness (Chtourou \& Souiden, 2010; Pai \& Huang, 2011; Maier, Laumer, \& Weitzel, 2013; Son et al., 2012; Mariani, Curcuruto, \& Gaetani, 2013).

\section{H6: Ease-of-use affects usefulness.}

The technology acceptance model (TAM) proposed by Davis (1989) and Davis, Bagozzi, and Warshaw (1989) as an instrument to predict the acceptance level of new technology by an organization or group developed based on the theory of reasoned action (TRA) stated by Fishbein and Ajzen (1975). Technology Acceptance Model (TAM) uses the usefulness and the perceived ease of use as independent variables to predict the actual use (Davis, 1989; Nguyen, 2020; Phan, Nguyen, \& Bui, 2019).
H7: Ease-of-use affects the use of smartphones

H8: Usefulness affects the use of smartphones

\section{Research Methods}

This study examined the relationship between variables that influence the Ease-of-Use and Usefulness of Davis's TAM model (1989). a hypothetical model presented in Figure 1 was obtained from previous studies. This study is an explanatory research with populations of batik craftsmen and textiles in the Bayat region, Klaten, Central Java. A questionnaire consisting of 30 questions with answers measured on a 5 -point Likert scale ranging from (1) strongly disagree to (5) strongly agree was employed to obtain the data. From 251 sets of data obtained, eight were not included in this study because they were considered incomplete or were disallowed due to incomplete entries. Thus, the samples involved in this study were 243 .

The age of the respondents who were smartphone users were ranging from the most users aged 21-30 years old $(50.2 \%)$, followed by $31-40$ years old $(46.1 \%)$, over 40 years old $(3.3 \%)$, and less than 20 years old $(0.4 \%)$. Based on their education, $91.4 \%$ of users were high school graduates, $5.8 \%$ of them were diploma graduates, $2.9 \%$ of them were $\mathrm{S} 1$ graduates.

\section{Results and Discussion}

Descriptive analysis was carried out with SPSS 17 for Windows to find a general description of respondents' responses about the indicators contained in the variables. Hypothesis testing in this study was conducted using the Generalized Structured Component Analysis (GSCA) method. The obtained results were presents as follows:

According to Table 1, it can be seen that all indicators used in the study had a significance of less than 0.05 . Thus, it can be concluded that all indicators were valid and feasible to be used in the study. Reliability testing showed that all variables had a Cronbach's Alpha value greater than 0.60. Therefore, it can be said that all concepts measuring the variables used in this study were reliable.

Test indexes in the GSCA analysis included Fit, Afit, GFI, and SRMR. The criteria for using GFI stated that if the value of goodness of fit is $\geq$ cut value $(0.90)$, then the construct formed is appropriate (fit or good fit). Meanwhile, if the GFI value is in the range of $0.8-0.9$, then the construct formed is declared marginal fit (quite feasible). Moreover, the criteria for using SRMR stated that if SRMR cut cut-off value (0.08), then the construct formed is appropriate (fit or good fit). However, if one of the goodness of fit has been fulfilled, then the model can be declared feasible. The results of the construct feasibility test were summarized in Table 2 . 
Table 1: Validity and Reliability Test Results

\begin{tabular}{|c|c|c|c|c|c|c|}
\hline \multirow[b]{2}{*}{ Variable / Indicator } & \multirow[b]{2}{*}{ Symbol } & \multicolumn{5}{|c|}{ Instrument Measurement Results } \\
\hline & & \multirow[t]{2}{*}{$\begin{array}{c}\text { Pearson } \\
\text { Correlation }\end{array}$} & \multirow[t]{2}{*}{$\begin{array}{c}\text { Sig. } \\
\text { (2-tailed) }\end{array}$} & $\begin{array}{c}\text { Alpha } \\
\text { Cronbach }\end{array}$ & \multicolumn{2}{|c|}{ Description } \\
\hline \multirow[t]{6}{*}{ Technical Support } & $\mathrm{X} 1$ & & & \multirow[t]{6}{*}{0.860} & & Reliable \\
\hline & $\mathrm{X} 11$ & 0.821 & 0.000 & & Valid & \\
\hline & $\mathrm{X} 12$ & 0.797 & 0.000 & & Valid & \\
\hline & $\mathrm{X} 13$ & 0.746 & 0.000 & & Valid & \\
\hline & $\mathrm{X} 14$ & 0.877 & 0.000 & & Valid & \\
\hline & $\mathrm{X} 15$ & 0.782 & 0.000 & & Valid & \\
\hline \multirow[t]{5}{*}{ Training } & $\mathrm{X} 2$ & & & \multirow[t]{5}{*}{0.882} & & Reliable \\
\hline & $\mathrm{X} 21$ & 0.805 & 0.000 & & Valid & \\
\hline & $\mathrm{X} 22$ & 0.888 & 0.000 & & Valid & \\
\hline & $\mathrm{X} 23$ & 0.886 & 0.000 & & Valid & \\
\hline & $\mathrm{X} 24$ & 0.859 & 0.000 & & Valid & \\
\hline \multirow[t]{4}{*}{ Job Relevance } & X3 & & & 0.836 & & Reliable \\
\hline & X31 & 0.934 & 0.000 & & Valid & \\
\hline & X32 & 0.926 & 0.000 & & Valid & \\
\hline & X33 & 0.755 & 0.000 & & Valid & \\
\hline \multirow[t]{4}{*}{ Management Support } & $\times 4$ & & & \multirow[t]{4}{*}{0.887} & & Reliable \\
\hline & $\mathrm{X} 41$ & 0.897 & 0.000 & & Valid & \\
\hline & $\mathrm{X} 42$ & 0.939 & 0.000 & & Valid & \\
\hline & $\mathrm{X} 43$ & 0.873 & 0.000 & & Valid & \\
\hline \multirow[t]{4}{*}{ Social Influence } & $\times 5$ & & & \multirow[t]{4}{*}{0.685} & & Reliable \\
\hline & X51 & 0.938 & 0.000 & & Valid & \\
\hline & X52 & 0.929 & 0.000 & & Valid & \\
\hline & X53 & 0.390 & 0.013 & & Valid & \\
\hline \multirow[t]{4}{*}{ Ease of Use } & X6 & & & \multirow[t]{4}{*}{0.906} & & Reliable \\
\hline & X61 & 0.983 & 0.000 & & Valid & \\
\hline & X62 & 0.838 & 0.000 & & Valid & \\
\hline & X63 & 0.927 & 0.000 & & Valid & \\
\hline \multirow[t]{5}{*}{ Usefulness } & $\times 7$ & & & \multirow[t]{5}{*}{0.869} & & Reliable \\
\hline & X71 & 0.584 & 0.000 & & Valid & \\
\hline & $\mathrm{X} 72$ & 0.949 & 0.000 & & Valid & \\
\hline & $\mathrm{X73}$ & 0.870 & 0.000 & & Valid & \\
\hline & $X 74$ & 0.935 & 0.000 & & Valid & \\
\hline \multirow[t]{6}{*}{ Use smartphone } & $\mathrm{Y} 1$ & & & \multirow[t]{6}{*}{0.839} & & Reliable \\
\hline & Y11 & 0.930 & 0.000 & & Valid & \\
\hline & Y12 & 0.697 & 0.000 & & Valid & \\
\hline & Y13 & 0.874 & 0.000 & & Valid & \\
\hline & Y14 & 0.504 & 0.001 & & Valid & \\
\hline & Y15 & 0.825 & 0.000 & & Valid & \\
\hline
\end{tabular}

Table 2: Results of the Feasibility Model Test

\begin{tabular}{|l|l|}
\hline Index & Value \\
\hline Fit & 0.638 \\
\hline Afit & 0.633 \\
\hline GFI & 0.972 \\
\hline SRMR & 0.247 \\
\hline
\end{tabular}




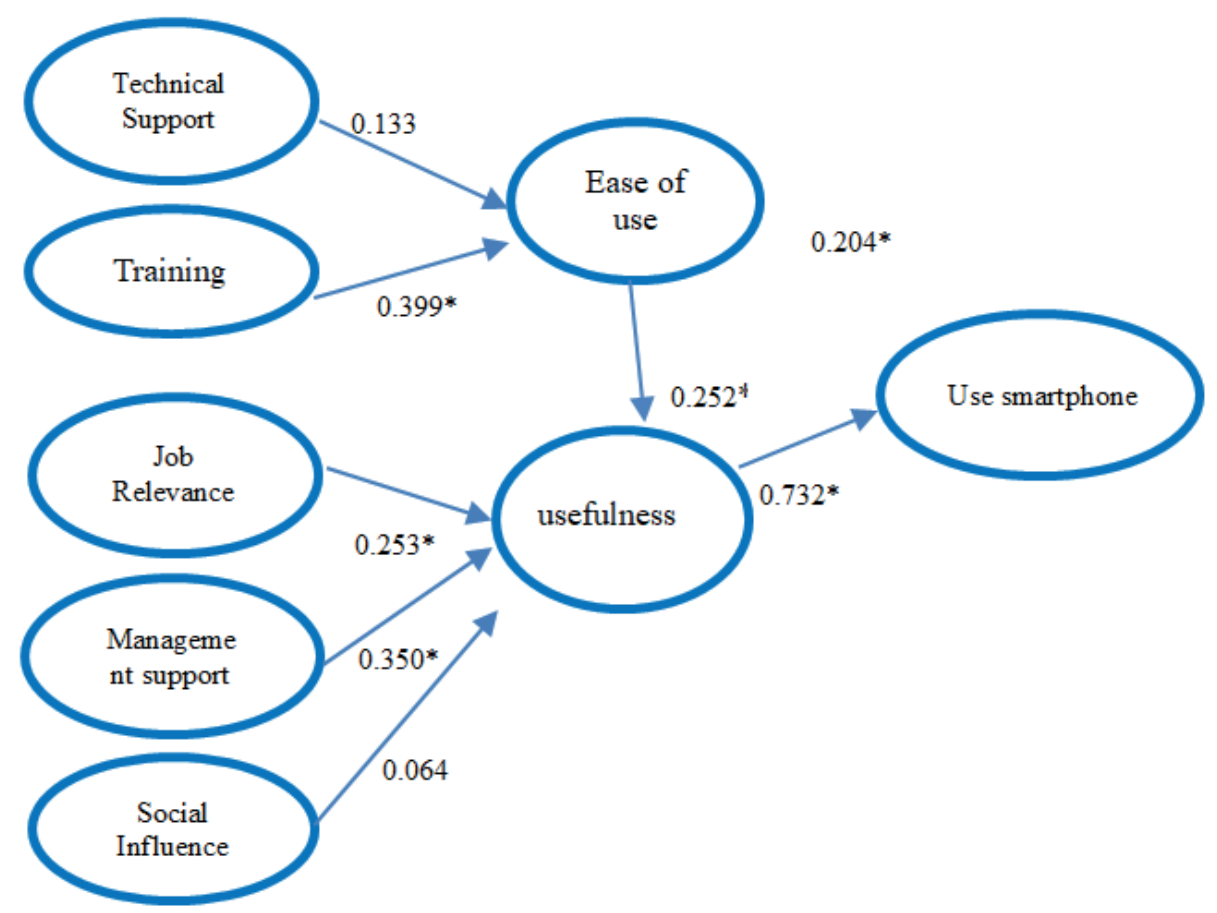

Figure 1: Path Diagram of the Research Findings

Table 3: Hypothesis Analysis of Direct Effect

\begin{tabular}{|c|l|c|c|c|c|}
\hline Hypothesis & \multicolumn{1}{|c|}{ Relationships among Variables } & Estimate & SE & CR & Description \\
\hline H1 & Technical Support $\rightarrow$ Ease of Use & 0.133 & 0.118 & 1.13 & Not Significant \\
\hline H2 & Training $\rightarrow$ Ease of Use & 0.399 & 0.086 & $4.66^{*}$ & Significant $^{*}$ \\
\hline H3 & Job Relevance $\rightarrow$ Usefulness & 0.253 & 0.076 & $3.31^{*}$ & Significant \\
\hline H4 & Management Support $\rightarrow$ Usefulness & 0.350 & 0.099 & $3.54^{*}$ & Significant \\
\hline H5 & Social Influence $\rightarrow$ Usefulness & 0.064 & 0.064 & 1.0 & Not Significant \\
\hline H6 & Ease of Use $\rightarrow$ Usefulness & 0.252 & 0.065 & $3.87^{*}$ & Significant \\
\hline H7 & Ease of Use $\rightarrow$ Use smartphone & 0.204 & 0.063 & $3.22^{*}$ & Significant \\
\hline H8 & Usefulness $\rightarrow$ Use the smartphone & 0.732 & 0.052 & $14.0^{*}$ & Significant \\
\hline
\end{tabular}

The results of the Generalized Structured Component Analysis (GSCA) of the hypothesis model were as shown in Figure 1.

Test criteria stated that if the critical ration (CR) was asterisked or critical ratio $(\mathrm{CR})$ table $\geq \mathrm{t}$-table $(\mathrm{t}=2.00$, alpha $=5 \%$ ). It could be said that there was a significant influence of exogenous variables on endogenous variables. The results of the analysis were served through the summary in Table 3.

Critical ratio (CR) between Technical Support and Ease-of-Use was 1.13. It means that $\mathrm{CR}<\mathrm{t}$-table $(\mathrm{t}=2.00$. alpha $=5 \%$ ). It can be interpreted that there was no significant direct effect of Technical Support on Ease-of-Use. This finding was in contrast to previous studies (Sanchez \& Hueros, 2010; Kwak et al., 2012). However, this finding supported the other previous findings (Son et al., 2012). Critical ratio between Training and Ease-of-Use was $4.66^{*}>\mathrm{t}$-table $(\mathrm{t}=2.00$, alpha $=5 \%)$. It means that Training had a significant positive effect on Ease-of-Use of supporting findings (Costa et al., 2016; Son et al., 2012; Kwak et al., 2012; Cascio, Mariadoss, \& Mouri, 2010). Behavior change is easily realized if the leader can create a supportive environment (Weill, 1992; Bajwa, Rai, \& Brennan, 1998). Critical ratio (CR) between Social influence and Usefulness was 1.0 . $\mathrm{CR}$ value $<\mathrm{t}$-table $(\mathrm{t}=2.00$, alpha $=5 \%)$ means that social influence does not significantly influence Usefulness. 
These findings were following mobile device research by Biljon and Kotze (2009), Montazemi and Saremi (2013), Son et al., (2012), Rodriguez and Trainor (2016). The test results served that the value of the critical ratio (CR) between the usefulness of the use of m-SFA was $3.87^{*}$. It was greater than $\mathrm{t}$-table $(\mathrm{t}=2.00$, alpha $=5 \%)$, which means that there was a significant relationship between the Ease-of-Use variable and the Usefulness variable. Ease-of-Use and Usefulness are the main variables in TAM (Davis \& Warshaw, 1992). They are the main divers for someone to use TAM. The findings of this study supported the research conducted by Davis (1992), Son et al. (2012), Maier, Laumer, and Weitzel (2012), Kwak et al. (2012), Alqudah (2014), Rajan and Baral (2015), Escobar-Rodriguez and Bartual-Sopena (2015), Costa et al. (2016), and Kapoor et al. (2014). Critical ratio (CR) between Ease-of-Use and Smartphone Use was 3.22*, where CR > $\mathrm{t}$-table $(\mathrm{t}=2.00$, alpha $=5 \%)$.

This condition indicates that there was a significant influence on the Ease-of-Use variable on Smartphone Use. This finding supported the research conducted by Ngai, Poon, and Chan (2005), Sánchez and Hueros (2010), Lin, Fofanah, and Liang (2011), Kwak et al. (2012), Abeka (2012), Montazemi and Saremi (2013), Mariani, Curcuruto, and Gaetani (2013), Rodriguez and Trainor (2016), and Rajan and Baral (2015). Applications that run on smartphones have simple features to make it easy for users. This will increase the perception of smartphone users that applications run on smartphones are easy and convenient to use. The value of the critical ratio (CR) between Usefulness to Use smartphone was $14.0 *$. It was greater than the value of $t$-table $(t=2$, Alpha $=5 \%$ ), meaning that there was a significant direct effect between the Usefulness variable. The increasing number of business applications that can be run through smartphones made smartphone use even higher. This finding supported the research conducted by Rajan and Baral (2015), Karjaluoto et al. (2014), Kwak et al. (2012), Venter, van Rensburg, and Davis (2012), Davis (1989), and Venkatesh et al. (2003).

\section{Conclusion}

Based on the findings of data analysis conducted using the GSCA software, it can be inferred that, of the eight hypotheses proposed, two hypotheses were not supported. Technical Support was not statistically significant for the ease-of-use. It is because the damage experienced can be easily resolved by a repair shop. Thus, they never worry about Technical Support. The findings of this study reinforce the importance of training during the implementation of new technology. This training can make the users understand how to use new technology. According to Venkatesh and Davis (2000), job relevance is a part of what they call the Cognitive Instrument variable, which influences eliciting perceptions of usefulness.
The findings in this study support the theory of acceptance of TAM2 technology. Management support influences the usefulness. This finding is following or reinforces the theory of acceptance of Igbaria technology (1997), which stated that management support as part of intra-organizational factors is a determinant of the perception of ease-of-use and perception of usefulness. Social influence has no significant effect on usefulness. However, the results of this study do not support the theory of acceptance of TAM technology. This is because this study was conducted when the smartphone was no longer said to be a new technology. According to Venkatesh (2003), Social Influence is an individual's perception that he or she always uses the latest technology. Ease-of-Use has a significant effect on usefulness. The finding of this study also supported the theory of technology acceptance of TAM2 proposed by Venkatesh and Davis (2000), which means that the TAM2 model is still relevant for knowing technology acceptance. Ease-of-Use has a significant effect on smartphone use.

The results of this study are in line with the Igbaria Technology Acceptance Model (1997), where the ease-of-use variable has a positive influence on technology acceptance and use. Usefulness has a significant effect on smartphone use. These findings reinforce the theory of acceptance of Igbaria technology (1997).

\section{References}

Abeka, S. O. (2012). Perceived Usefulness, Ease of Use, Organizational and Bank Support As Determinants of Adoption of Internet Banking in East Africa. International Journal of Academic Research in Business and Social Sciences, 2(10), 97-112.

Ajzen, I. (1985). From Intentions to Actions: A Theory of Planned Behavior. In: J. Kuhl (ed.), Action control: From cognition to behavior (pp. 11-39). New York, NY: Springer-Verlag.

Alqudah, A. A. (2014). Accepting Moodle by academic staff at the University of Jordan: Applying and extending TAM in technical support factors. European Scientific Journal, 10(18). https://doi.org/10.19044/esj.2014.v10n18p\%25p

Ardiansah, M. N., Chariri, A., Rahardja, S., \& Udin, U. (2020). The effect of electronic payments security on e-commerce consumer perception: An extended model of technology acceptance. Management Science Letters, 10(7), 1473-1480.

Bajwa, D. S., Rai, A., \& Brennan, I. (1998). Key Antecedents of Executive Information System Success: A Path Analytic Approach. Decision Support Systems, 22(1), 31-43.

Barhoumi, C. (2016). User acceptance of the e-information service as information resource: a new extension of the technology acceptance model. New Library World, 117(9/10). http://dx.doi. org/10.1108/NLW-06-2016-0045.

Biljon V., \& Kotze, P. (2009). Cultural factors in a mobile phone adoption and usage model. Journal of Universal Computer Science, 14(16), 2650-2679. 
Cascio, R., Mariadoss, B. J., \& Mouri, N. (2010). The impact of management commitment alignment on salespersons' adoption of sales force automation technologies: An empirical investigation. Industrial Marketing Management, 39(7), 1088-1096.

Choi, S. (2018). What promotes smartphone-based mobile commerce? Mobile-specific and self-service characteristics. Internet Research, 28(1), 105-122, https://doi.org/10.1108/ IntR-10-2016-0287

Chtourou, M. S., \& Souiden N. (2010). Rethinking the TAM model: time to consider fun. Journal of Consumer Marketing, 27(4), 336-344.

Costa, C. J., Ferreira, E., Bento, F., \& Aparicio, M. (2016). Enterprise resource planning adoption and satisfaction determinants. Computers in Human Behavior, 63, 659-671.

Davis, F. D., Bagozzi, R. P., \& Warshaw, P. R. (1989). User acceptance of computer technology: a comparison of two theoretical models. Management Science, 35, 982-1003.

Davis, F. D. (1989). Perceived usefulness, perceived ease of use, and user acceptance of information technology. MIS Quarterly, 13(3), 319-339.

Davis, F. D., \& Warshaw, P. R. (1992). Extrinsic and Intrinsic Motivation to Use Computers in the Workplace. Journal of Applied Social Psychology, 22(4), 1111-1132.

eMarketer. (2017). Worldwide ad spending: the eMarketer forecast for 2017. Retrieved February 20, 2019 from: https://bit. ly/2GwlrWR.

Escobar-Rodríguez, T., \& Bartual-Sopena, L. (2015). Impact of cultural factors on attitude toward using ERP systems in public hospitals. Revista de Contabilidad, 18(2), 127-137.

Fishbein, M., \& Ajzen, I. (1975). Belief, Attitude, Intention, and Behaviour: An Introduction to Theory and Research. Reading, MA: Addision-Wesley.

Grob, M. (2015). Mobile shopping: a classification framework and literature review. International Journal of Retail and Distribution Management, 43(3), 221-241.

Igbaria, M., Zinatelli, N., Cragg, P., \& Cavaye, A.L.M. (1997). Personal computing acceptance factors in small firms: a structural equation model. MIS Quarterly, 21(3), 279-305.

Igbaria, M. (1994). An examination of the factors contributing to microcomputer technology acceptance. Account ManagementInformation Technology, 4(4), 205-224.

Karjaluoto, H., Töllinen, A., Pirttiniemi, J., \& Jayawardhena, C. (2014). Intention to use mobile customer relationship management systems. Industrial Management \& Data Systems, 114(6), 966-978.

Kapoor, K., Dwivedi, Y, Nial, P. C., Lal, B., \& Weerakkody V. (2014). RFID integrated systems in libraries: extending TAM model for empirically examining the use. Journal of Enterprise Information Management, 27(6), 731-758. http://dx.doi. org/10.1108/JEIM-10-2013-0079

Kwak, Y. H., Park, J., Chung, B. Y., \& Ghosh, S. (2012). Understanding end-users' acceptance of enterprise resource planning (ERP) system in project-based sectors. IEEE Transactions on Engineering Management, 59(2), 266-277.

Lee, J. W., Becker, K., \& Potluri, R. M. (2016). Antecedents of Corporate Adoption of Social Media and the Role of the Technology Acceptance Model in the Path. Journal of Asian Finance, Economics and Business, 3(2), 67-76. doi: https://doi. org/10.13106/jafeb.2016.vol3.no2.67

Lee, Y., Lee, J., \& Lee, Z. (2006). Social influence on technology acceptance behavior: self-identity theory perspective. Database Advance Systems, 37(2), 60-75.

Lewis, W., Agarwal, R., \& Sambamurthy, V. (2003). Sources of influence on beliefs about information technology use: an empirical study of knowledge workers. MIS Quarterly, 27(4), 657-678.

Lin, F., Fofanah, S. S., \& Liang, D. (2011). Assessing citizen adoption of e-Government initiatives in Gambia: A validation of the technology acceptance model in information systems success. Government Information Quarterly, 28(2), 271-279.

Maier, C., Laumer, S., Eckhardt, A., \& Weitzel, T. (2013). Analyzing the impact of HRIS implementations on HR personnel's job satisfaction and turnover intention. The Journal of Strategic Information Systems, 22(3), 193-207.

Marakarkandy B., Yajnik, N., \& Dasgupta, C. (2017). Enabling internet banking adoption: An empirical examination with an augmented technology acceptance model (TAM). Journal of Enterprise Information Management, 30(2), 263-294. https:// doi.org/10.1108/JEIM-10-2015-0094

Mariani, M. G., Curcuruto, M., \& Gaetani, I. (2013). Training opportunities, technology acceptance, and job satisfaction: A study of Italian organizations. Journal of Workplace Learning, 25(7), 455-475.

Marinkovic V., \& Kalinic, Z. (2017). Antecedents of customer satisfaction in mobile commerce: Exploring the moderating effect of customization. Online Information Review, 41(2), 138-154. https://doi.org/10.1108/OIR-11-2015-0364

Montazemi, A. R., \& Saremi, H. Q. (2013). Factors Affecting Internet Banking Pre-Usage Expectation Formation. In: Proceedings of the $46^{\text {th }}$ Hawaii International Conference on System Sciences (pp. 4666-4675). IEEE.

Ngai, E. W. T., Poon, J. K. L., \& Chan, Y. H. C. (2007). Empirical examination of the adoption of WebCT using TAM. Computers in Education, 48(2), 250-267.

Nguyen, O. T. (2020). Factors Affecting the Intention to Use Digital Banking in Vietnam. Journal of Asian Finance, Economics, and Business, 7(3), 303-310. doi: https://doi.org/10.13106/ jafeb.2020.vol7.no3.303

Nguyen, X. T., \& Luu, Q. K. (2020). Factors Affecting Adoption of Industry 4.0 by Small-and Medium-Sized Enterprises: A Case in Ho Chi Minh City, Vietnam. Journal of Asian Finance, Economics, and Business, 7(6), 255-264. doi: https://doi. org/10.13106/jafeb.2020.vol7.no6.255

Pai, F. Y., \& Huang, K. I. (2011). Applying the technology acceptance model to the introduction of healthcare information 
systems. Technological Forecasting and Social Change, 78(4), 650-660.

Park, H. E., Yap, S. F. C., \& Makkar, M. (2019). A laddering study of motivational complexities in mobile shopping. Marketing Intelligence \& Planning, 37(2), 182-196. https://doi. org/10.1108/MIP-03-2018-0104

Pérez, M. P., Sánchez, A. M., de Luis Carnicer, P., \& Jiménez, M. J. V. (2004). A technology acceptance model of innovation adoption: the case of teleworking. European Journal of Innovation Management, 7(4), 280-291.

Phan, D. T. T., Nguyen, T. T. H., \& Bui, T. A. (2019). Going beyond Border? Intention to Use International Bank Cards in Vietnam. Journal of Asian Finance, Economics and Business, 6(3), 315-325. doi: https://doi.org/10.13106/jafeb.2019.vol6.no3.315

Pipitwanichakarn, T., \& Wongtada, N. (2019). Mobile commerce adoption among the bottom of the pyramid: a case of street vendors in Thailand. Journal of Science and Technology Policy Management, 10(1), 193-213. https://doi.org/10.1108/ JSTPM-12-2017-0074

Ragu-Nathan, B.S., Apigian, C.H., Ragu-Nathan, T.S., and Tu, Q. (2004). A path analytic study of the effect of top management support for information systems performance. Omega 32(6), $459-471$

Rajan, C. A., \& Baral, R. (2015). Adoption of ERP system: An empirical study of factors influencing the usage of ERP and its impact on end user. IIMB Management Review, 27(2), 105-117.

Rodriguez, M., \& Trainor, K. (2016). A conceptual model of the drivers and outcomes of mobile CRM application adoption. Journal of Research in Interactive Marketing, 10(1), 67-84.
Rogers, E. (1995). The Diffusion of Innovations. New York, NY: The Free Press.

Sagib, G. K., \& Zapan, B. (2014). Bangladeshi mobile banking service quality and customer satisfaction and loyalty. Management \& Marketing, 9(3), 331-346.

Sánchez, R. A., \& Hueros, A. D. (2010). Motivational factors that influence the acceptance of Moodle using TAM. Computers in Human Behavior, 26(6), 1632-1640.

Son, H., Park, Y., Kim, C., \& Chou, J.S. (2012). Toward an understanding of construction professionals' acceptance of mobile computing devices in South Korea: An extension of the technology acceptance model. Automation in Construction, 28, 82-90.

Taylor, S., \& Todd, P. (1995). Assessing IT Usage: The Role of Prior Experience. MIS Quarterly, 19(2), 561 - 570.

Venkatesh, V., \& Morris, M. G. (2000). Why don't men ever stop to ask for directions? Gender, social influence, and their role in technology acceptance and usage behavior. MIS Quarterly, 24(1), 115-139.

Venkatesh, V., Morris, M. G., Davis, G. B., \& Davis, F. D. (2003). User acceptance of information technology: Toward a unified view. MIS Quarterly, 27(3), 425-478.

Venkatesh, V., \& Davis, F. D. (2000). A theoretical extension of the technology acceptance model: four longitudinal field studies. Management Science, 46(2), 186-204.

Venter, P., van Rensburg, J. M., \& Davis, A. (2012). Drivers of learning management system use in a South African open and distance learning institution. Australasian Journal of Educational Technology, 28(2), 183-198. 